\title{
Perancangan Sistem Pengukuran Kinerja Terintegrasi Pada Program Studi Teknik Mesin Universitas Udayana
}

\author{
I Made Dwi Budiana Penindra ${ }^{1)^{*}}$, Dewa Made Priyantha Wedagama ${ }^{2)}$ \\ 1) Jurusan Teknik Mesin Universitas Udayana, Kampus Bukit Jimbaran Bali \\ 2) Jurusan Teknik Sipil, Universitas Udayana, Kampus Bukit Jimbaran Bali
}

doi: 10.24843/JEM.2018.v11.i01.p04

\begin{abstract}
Abstrak
Jurusan Teknik Mesin merupakan salah satu jurusan yang terakreditasi A. Jurusan Teknik Mesin Universitas Udayana pada tahun 2016 telah berhasil mempertahankan akreditasi A yang diperoleh sejak tahun 2011. Salah satu penunjang keberhasilan tersebut adalah karena telah dimilikinya sistem pengukuran kinerja yang dihasilkan penulis pada tahun 2015 dimana sistem tersebut telah mampu memantau kinerja jurusan secara berkesinambungan. Walaupun sistem pengukuran kinerja tersebut telah digunakan, tetapi pada implementasinya masih banyak kekurangan yang dimiliki oleh sistem tersebut terutama karena sistem tersebut masih berbentuk manual. Kekurangan lain juga dapat dilihat dari hasil penelitian penulis tahun 2016 yang menunjukkan bahwa dari Importance Performance Analysis (IPA) rata-rata persepsi dari mahasiswa sebesar 2,91 masih dibawah rata-rata ekspektasi mereka yaitu 3,14. Pada penelitian ini dilakukan perancangan kembali sistem pengukuran kinerja yang terintegrasi berdasarkan hasil-hasil penelitian di tahun 2015 dan 2016 dengan metode Performance Prism dimana metode tersebut diintegrasikan dengan beberapa metode yaitu Integrated Performance Measurement Systems (IPMS) di dalam penentuan Key Performande Indicator (KPI) yang menjadi indikator penentu kinerja yang kemudian dibantu menggunakan metode Analytical Hierarcy Process (AHP) di dalam pemberian bobot masing-masing KPI. Setelah KPI memiliki bobot kemudian dilakukan scoring secara menyeluruh dengan Metode Objectives Matrix (OMAX) sehingga dihasilkan angka indeks per periode yang menjadi acuan tingkat kinerja jurusan, serta Traffic Light System (TLS) untuk mengetahui KPI mana yang memerlukan perbaikan berdasarkan warna. Dari hasil penelitian didapatkan hasil Performance Indicator dari periode 1 sebesar 322,8 dan mengalami peningkatan 7,6\% dibanding Performance Indicator rata-rata 300. Performance Indicator dari periode 2 sebesar 352,50 dan mengalami peningkatan 9,2\% dibanding periode 1. Performance Indicator dari periode 3 sebesar 354,66 dan mengalami sedikit peningkatan 0,61\% dibanding periode 2. Performance Indicator dari periode 4 sebesar 354,52 dan mengalami sedikit penurunan $0,04 \%$ dibanding periode 3. Performance Indicator dari periode 5 sebesar 573,35 dan mengalami peningkatan $61,73 \%$ dibanding periode 4. Performance Indicator dari periode 6 sebesar 606,68 dan mengalami peningkatan 5,81\% dibanding periode 5 dan merupakan periode dengan Performance Indicator tertinggi dalam sistem pengukuran ini.
\end{abstract}

Kata kunci: Metode Objectives Matrix (OMAX), metode Performance Prism, metode Integrated Performance Measurement Systems (IPMS), Key Performance Indicator (KPI), metode Analytical Hierarcy Process $(A H P)$

\begin{abstract}
Department of Mechanical Engineering Udayana University in 2016 has managed to maintain the A accreditation obtained since 2011. One of the supporting success is because it has owned performance measurement system generated by the author in 2015 where the system has been able to monitor the performance of majors on an ongoing basis. Although the performance measurement system has been used, but in its implementation there are still many shortcomings possessed by the system mainly because the system is still in the form of manual. Another disadvantage can also be seen from the results of research authors of 2016 which shows that from the Importance Performance Analysis (IPA) average perception of students of 2.91 is still below the average of their expectations of 3.14. In this research, re-design of integrated performance measurement system based on the results of research in 2015 and 2016 with Performance Prism method where the method is integrated with several methods of Integrated Performance Measurement Systems (IPMS) in the determination of Key Performande Indicator (KPI) a performance indicator that is then assisted using the Analytical Hierarcy Process (AHP) method in the weighting of each KPI. After $\mathrm{KPI}$ has weight then scoring thoroughly with Objectives Matrix (OMAX) method so that the result of index number per period become reference of department performance level, and Traffic Light System (TLS) to know which KPI need improvement based on color. From the research results obtained Performance Indicator from period 1 of 322.8 and increased $7.6 \%$ compared to Performance Indicator average 300. Performance Indicator from period 2 amounted to 352.50 and increased $9.2 \%$ compared to period 1. Performance Indicator from period 3 was 354.66 and slightly increased by $0.61 \%$ compared to period 2 . Performance Indicator from period 4 was 354.52 and decreased slightly $0.04 \%$ compared to period 3. Performance Indicator from period 5 was 573.35 and an increase of $61.73 \%$ compared to period 4. Performance Indicator from period 6 of 606.68 and increased $5.81 \%$ compared to period 5 and is the period with the highest Performance Indicator in this measurement system.
\end{abstract}

Keywords: Objectives Matrix (OMAX) method, Performance Prism method, Integrated Performance Measurement Systems (IPMS) method, Key Performance Indicator (KPI), Analytical Hierarcy Process (AHP) method. 


\section{Pendahuluan}

Jurusan Teknik Mesin Universitas Udayana pada tahun 2016 telah berhasil mempertahankan akreditasi A untuk yang kedua kalinya dimana akreditasi pertama diperoleh sejak tahun 2011. Salah satu penunjang keberhasilan jurusan tersebut adalah karena telah dimilikinya sistem pengukuran kinerja yang dihasilkan penulis pada tahun 2015 dimana sistem tersebut telah mampu memantau kinerja jurusan secara berkesinambungan.

Walaupun sistem pengukuran kinerja tersebut telah digunakan, tetapi pada implementasinya masih banyak kekurangan yang dimiliki oleh sistem tersebut terutama karena sistem tersebut masih berbentuk manual. Kekurangan lain juga dapat dilihat dari hasil penelitian penulis tahun 2016 yang menunjukkan bahwa dari Importance Performance Analysis (IPA) rata-rata persepsi dari mahasiswa sebesar 2,91 masih dibawah rata-rata ekspektasi mereka yaitu 3,14 .

Penelitian akan dilakukan perancangan kembali sistem pengukuran kinerja yang terintegrasi berdasarkan hasil-hasil penelitian di tahun 2015 dan 2016 dengan metode Performance Prism dimana metode tersebut diintegrasikan dengan beberapa metode yaitu Integrated Performance Measurement Systems (IPMS) di dalam penentuan Key Performance Indicator (KPI) yang menjadi indikator penentu kinerja yang kemudian dibantu menggunakan metode Analytical Hierarcy Process (AHP) di dalam pemberian bobot masing-masing KPI. Setelah KPI memiliki bobot kemudian dilakukan scoring secara menyeluruh dengan Metode Objectives Matrix (OMAX) sehingga dihasilkan angka indeks per periode yang menjadi acuan tingkat kinerja jurusan, serta Traffic Light System (TLS) untuk mengetahui KPI mana yang memerlukan perbaikan berdasarkan warna. Sistem pengukuran kinerja ini akan dibuat berbasis web sehingga diharapkan nantinya jurusan dapat mengintegrasikan dengan sistem informasi yang telah ada saat ini.

\section{Metode Penelitian}

Metode penelitian menjelaskan bagaimana langkah-langkah penelitian dilakukan atau tahapan-tahapan apa saja yang dilakukan dalam perhitungan produktivitas sehingga hasil dari analisa dapat memberikan hasil yang sesuai dengan tujuan yang diharapkan dan pemecahan terhadap masalah dapat memberikan jawaban atau rumusan yang dipaparkan sebelumnya. Langkah-langkah atau rincian dari metode penelitian yang diharapkan adalah mengikut tahapan sebagai berikut:

\subsection{Lokasi Penelitian}

Penelitian ini dilakukan di Fakultas Teknik Jurusan Teknik Mesin Universitas Udayana Kampus Bukit Jimbaran.

\subsection{Pemilihan \\ Metode \\ Pengukuran Produktivitas}

Dalam merancang system pengukuran kinerja terdapat banyak metode yang dapat digunakan. Tiap-tiap metode tersebut mempunyai manfaat sendiri-sendiri. Adapun rancangan sistem pengukuran kinerja yang akan didesain adalah menggabungkan empat metode yaitu Metode Performance Prism, Metode Objectives Matrix (OMAX), Integrated Performance Measurement Systems (IPMS), Analytical Hierarcy Process $(A H P)$ serta Traffic Light System.

\subsection{Jenis dan Metode Pengumpulan Data}

Data yang dikumpulkan dalam penelitian ini adalah data primer dan data sekunder yang terdiri dari data kualitatif dan kuantitatif. Data primer yang dicari adalah data yang bersifat umum dan data pokok yang menunjang penelitian ini.

\subsection{Identifikasi Indikator-Indikator atau Kriteria Produktivitas yang Akan Diukur.}

Penentuan terhadap criteria produktivitas / Key Performance Indicator (KPI) mengikuti langkahlangkah sebagai berikut:

\section{Stakeholder requirement.}

Pendekatan yang akan digunakan adalah performance prism dan IPMS dimana pada tiaptiap level bisnis (organisasi) harus diketahui siapa saja stakeholder-nya atau pihak-pihak yang berkepentingan pada bisnis tersebut. Selanjutnya diidentifikasikan permintaan/keinginan (requirement) mereka terhadap bisnis yang diistilahkan dengan Stakeholder Requirement. Stakeholder dapat meliputi; pemegang saham / pemilik, lingkungan sosial, pegawai / karyawan, pemerintah / instansi lain.

\section{External Monitoring.}

External monitor dilakukan untuk mengetahui posisi organisasi terhadap pesaing dan performansi/kinerja jurusan-jurusan yang lain. Menentukan tujuan-tujuan (objectives) Jurusan.

3. Menentukan ukuran-ukuran kinerja (measures) yang biasa disebut KPI.

\subsection{Pemberian Bobot Dari Masing-Masing KPI Yang Diukur}

Pemberian bobot dari masing-masing KPI dimulai dari pembuatan Hierarki KPI, penyusunan, penyebaran, pengisian kuesioner. Setelah isian dinyatakan konsisten $(\mathrm{CR}<0,1)$ maka langkah selanjutnya pemberian bobot pada masing-masing $\mathrm{KPI}$. 


\subsection{Pengolahan Data Atau Pengukuran Kriteria Produktivitas}

Setelah data-data terkumpul dari hasil penelitian yang dilakukan maka langkah selanjutnya adalah melakukan pengukuran, pengolahan, dan analisa pada tiap-tiap periode tahun yang ditetapkan masing-masing KPI dengan menggunakan metode yang telah ditetapkan sehingga tingkat produktivitas setiap tahunnya dapat ditentukan.

\subsection{Evaluasi Produktivitas}

Setelah pengukuran produktivitas dilakukan maka selanjutnya adalah evaluasi berdasarkan data pengukuran terhadap masing-masing $\mathrm{KPI}$ yang telah dianalisis dan disajikan melalui suatu laporan produktivitas. Selanjutnya hasil evaluasi ini akan dapat ditentukan KPI-KPI yang mengalami kenaikan ataupun penurunan tiap tahunnya untuk dilakukan langkah perbaikan pada periode berikutnya terhadap KPI yang mengalami penurunan.

\section{Hasil dan Pembahasan}

Adapun pendekatan yang dilakukan untuk menentukan kriteria produktivitas adalah melalui pendekatan dengan Performance Prism dan Integrated Performance Measurement System (IMPS). Adapun hasil rekapitulasi dari kuesioner yang di sebarkan disajikan dalam Tabel 1.

Selanjutnya dari objectives yang terdapat pada tabel diatas dilakukan pengukuran terhadap masing-masing objectives dengan tujuan mengetahui tingkat pencapaian tiap-tiap objectives yang di identifikasi melalui Key Performance Indicator (KPI) dan Formula KPI, seperti disajikan dalam Tabel 2.

Tabel 1. Rekapitulasi kuesioner dengan pendekatan IMPS

\begin{tabular}{|c|c|c|c|}
\hline No & $\begin{array}{l}\text { Perspektif } \\
\text { IPMS } \\
\text { (Stakeholder) }\end{array}$ & Stakeholder Satisfaction & Stakeholder Contribution \\
\hline 1. & Jurusan & $\begin{array}{l}\text { 1. Peminat meningkat } \\
\text { 2. Proporsi keuangan untuk jurusan ditingkatkan. } \\
\text { 3. Kualitas SDM mahasiswa baru meningkat. } \\
\text { 4. Ruang kelas untuk jurusan ditambah. } \\
\text { 5. Meningkatnya minat baca mahasiswa } \\
\text { 6. Artikel Ilmiah, penelitian dan pengabdian yang dilakukan } \\
\text { dosen meningkat. } \\
\text { 7. Bertambahnya dosen bergelar doktor dan profesor. } \\
\text { 8. Disiplin semua dosen, pegawai dan mahasiswa } \\
\text { meningkat. } \\
\text { 9. Dosen memperoleh HAKI }\end{array}$ & $\begin{array}{l}\text { 10. Mengatur segala administrasi kegiatan belajar } \\
\text { mengajar } \\
\text { 11. Penataan sarana dan prasarana penunjang } \\
\text { perkuliahan. } \\
\text { 12. Penghubung antara kampus, pemerintah dan } \\
\text { industri }\end{array}$ \\
\hline \multirow[t]{3}{*}{2.} & Mahasiswa & $\begin{array}{l}\text { 13. Spot Wifi diperbanyak dan sinyal di perkuat. } \\
\text { 14. Taman internet dan tempat duduk di area teknik } \\
\text { mesin diperbanyak. } \\
\text { 15. Areal parkir lebih di buat hijau. } \\
\text { 16. Tempat sampah di perbanyak } \\
\text { 17. Dosen datang tepat waktu } \\
\text { 18. Pengadaan loker untuk mahasiswa } \\
\text { 19. Pemberian materi sesuai dengan SAP, GBPP dan } \\
\text { silabus yang ber-KBK } \\
\text { 20. Toilet bersih dan tak berbau } \\
\text { 21. Penyampaian materi menggunakan media bantu ajar } \\
\text { 22. Lingkungan kampus terhindar dari binatang liar serta } \\
\text { ditambah penerangan yang baik. } \\
\text { 23. Tersedianya modul atau buku ajar pada setiap mata } \\
\text { kuliah } \\
\text { 24. Jumlah buku pada ruang baca diperbanyak } \\
\text { 25. Ruang kelas yang ada di perbaiki. } \\
\text { 26. Ruang kelas ditambah serta ditambah fasilitas } \\
\text { olahraga } \\
\text { 27. Membangun Kantin yang lebih baik. } \\
\text { 28. Student center dipindah ke bukit. } \\
\text { 29. Kegiatan kemahasiswaan akademik maupun non } \\
\text { akademik ditingkatkan } \\
\text { 30. Laboratorium di perbaiki serta pengadaan alat praktek } \\
\text { lebih lengkap lagi } \\
\text { 31. Pengaturan jadwal diperbaiki karena banyak jadwal } \\
\text { terbentur. }\end{array}$ & $\begin{array}{l}\text { 32. Terlibat aktif di setiap kegiatan HMM } \\
\text { 33. Pembayaran SPP } \\
\text { 34. Mengikuti lomba-lomba baik akademis maupun } \\
\text { non akademis mewakili HMM } \\
\text { 35. Memberikan kritik melalui quisioner tentang } \\
\text { kinerja jurusan } \\
\text { 36. Memberi poin terhadap akreditasi jurusan } \\
\text { 37. Membantu jurusan di dalam promosi jurusan } \\
\text { 38. Menjaga dan memelihara semua fasilitas yang } \\
\text { ada. } \\
\text { 39. Mengikuti program PKM } \\
\text { 40. Terlibat dalam penelitian dan pengabdian } \\
\text { dosen. }\end{array}$ \\
\hline & $\begin{array}{l}\text { Orang Tua } \\
\text { Mahasiswa }\end{array}$ & $\begin{array}{l}\text { 41. Waktu studi lebih singkat. } \\
\text { 42. Tingkat kelulusan meningkat } \\
\text { 43. IPK tinggi } \\
\text { 44. Daya serap dunia kerja meningkat } \\
\text { 45. Biaya kuliah rendah }\end{array}$ & $\begin{array}{l}\text { 46. Menjadi pengawas bagi jalannya perkuliahan } \\
\text { 47. Membantu kegiatan kemahasiswaan }\end{array}$ \\
\hline & Dosen & $\begin{array}{l}\text { 48. Pengukuran kinerja dibuat lebih baik. } \\
\text { 49. Perlu ruang untuk dosen } \\
\text { 50. Tersedianya media bantu pengajaran }\end{array}$ & $\begin{array}{l}\text { 54. Dosen memperoleh HAKI } \\
\text { 55. Dosen memperoleh penelitian dan pengabdian }\end{array}$ \\
\hline
\end{tabular}




\begin{tabular}{|c|c|c|c|c|}
\hline & & & $\begin{array}{l}\text { Melanjutkan studi lanjut } \\
\text { Mengikuti pelatihan tentang pengajaran } \\
\text { Alat Laboratorium lebih diperbanyak }\end{array}$ & $\begin{array}{l}\text { 56. Terlibat dalam semua aktivitas jurusan } \\
\text { 57. Menjalin kerjasama dengan instansi pemerintah } \\
\text { maupun swasta }\end{array}$ \\
\hline & $\begin{array}{l}\text { Pegawai/tekni } \\
\text { si }\end{array}$ & $\begin{array}{l}58 . \\
59 . \\
60 . \\
61 . \\
62 .\end{array}$ & $\begin{array}{l}\text { Lebih dilibatkan dalam semua acara jurusan termasuk } \\
\text { suka duka } \\
\text { Kesejahteraan pegawai lebih diperhatikan } \\
\text { Sarana dan prasarana laboratorium ditingkatkan } \\
\text { Pengadaan pakaian praktikum } \\
\text { Pelatihan sesuai bidang masing-masing }\end{array}$ & $\begin{array}{l}\text { 63. Membantu menyelenggarakan administrasi } \\
\text { jurusan } \\
\text { 64. Membantu menyelenggarakan praktikum } \\
\text { 65. Membantu pemeliharaan sarana jurusan }\end{array}$ \\
\hline 3. & Masyarakat & & $\begin{array}{l}\text { Pendampingan desa dalam memanfaatkan dana } \\
\text { desa. } \\
\text { Lulusan dapat mengaplikasikan ilmu di masyarakat } \\
\text { Kegiatan pengabdian kepada masyarakat } \\
\text { ditingkatkan } \\
\text { Membina UMKM terutama yang berkaitan dengan } \\
\text { teknik mesin }\end{array}$ & $\begin{array}{l}\text { 70. Menerima dosen dan mahasiswa dalam } \\
\text { penelitian dan pengabdian salah satunya KKN } \\
\text { 71. Membantu mencari solusi terutama masalah- } \\
\text { masalah di masyarakat }\end{array}$ \\
\hline \multirow[t]{2}{*}{4.} & Alumni & $\begin{array}{l}72 . \\
73 . \\
74 . \\
75 . \\
76 .\end{array}$ & $\begin{array}{l}\text { Sosialisasi program PII lebih digencarkan. } \\
\text { Memiliki gedung alumni sebagai tempat pertemuan } \\
\text { alumni. } \\
\text { Waktu tunggu untuk mendapatkan kerja lebih singkat } \\
\text { Lulusan relevan dengan dunia kerja. } \\
\text { Aktivitas badan ikatan alumni ditingkatkan. }\end{array}$ & $\begin{array}{l}\text { 77. Memberi masukan untuk penyusunan silabus. } \\
\text { 78. Telah terbentuknya badan ikatan alumni. } \\
\text { 79. Membantu dalam kegiatan HUT jurusan } \\
\text { 80. Menyediakan informasi tentang peluang kerja. }\end{array}$ \\
\hline & $\begin{array}{l}\text { Institusi } \\
\text { Swasta/pemeri } \\
\text { ntah } \\
\text { pengguna } \\
\text { lulusan }\end{array}$ & $\begin{array}{l}81 . \\
82 . \\
83 .\end{array}$ & $\begin{array}{l}\text { Lulusan menguasai bahasa inggris pasif maupun aktif } \\
\text { Lulusan memiliki soft skill dan kemampuan } \\
\text { komunikasi yang baik } \\
\text { Lulusan mampu berpikir kreatif, inovatif \& mengikuti } \\
\text { perkembangan. }\end{array}$ & $\begin{array}{l}\text { 84. Menyediakan praktek kerja lapangan bagi } \\
\text { mahasiswa } \\
\text { 85. Menyediakan lapangan pekerjaan bagi lulusan } \\
\text { 86. Menyediakan beasiswa bagi mahasiswa } \\
\text { 87. Menyalurkan CSR melalui kerjasama dengan } \\
\text { jurusan. } \\
\text { 88. Menjadi sponsor dalam kegiatan mahasiswa } \\
\text { dan jurusan }\end{array}$ \\
\hline
\end{tabular}

Tabel 2. Identifikasi Key Performance Indicator (KPI)

\begin{tabular}{|c|c|c|}
\hline Objectives & Key Performance Indicators & Formula KPI \\
\hline \multirow{6}{*}{$\begin{array}{l}\text { Peningkatan } \\
\text { kualitas Dosen dan } \\
\text { pegawai. }\end{array}$} & 1. Rasio Pendidikan Dosen & $\{($ Jumlah dosen S3, Guru Besar)/(total dosen tetap) $\} \times 100 \%$ \\
\hline & 2. Rasio dosen yang telah mengikuti pelatihan & $\{($ Jumlah dosen yang telah mengikuti P2KBK)/(total dosen tetap) $\} \times 100 \%$ \\
\hline & 3. Rasio pegawai yang telah mengikuti pelatihan & $\begin{array}{l}\{(\text { Jumlah pegawai yangg telah mengikuti pelatihan)/(total pegawai tetap) }\} x \\
100 \%\end{array}$ \\
\hline & $\begin{array}{l}\text { 4. Rasio Dosen yang memiliki Sertifikat Pendidik } \\
\text { Profesional. }\end{array}$ & $\{($ Jumlah dosen yang telah memiliki serdos)/(total dosen tetap) $\} \times 100 \%$ \\
\hline & $\begin{array}{l}\text { 5. Rasio Rata-rata beban dosen per semester, atau rata- } \\
\text { rata FTE (Fulltime Teaching Equivalent) }\end{array}$ & $\{($ Rata-rata FTE $) /(16 \mathrm{SKS})\} \times 100 \%$ \\
\hline & $\begin{array}{l}\text { 6. Karya-karya PS/institusi yang telah memperoleh } \\
\text { perlindungan Hak atas Kekayaan Intelektual (HaKI) }\end{array}$ & $\{($ Jumlah HaKI)/(total dosen tetap $\} \times 100 \%$ \\
\hline \multirow{4}{*}{$\begin{array}{c}\text { Peningkatan sarana } \\
\text { dan kualitas proses } \\
\text { belajar mengajar }\end{array}$} & 7. Rasio tingkat kehadiran dosen & $\{($ Jumlah kehadiran dosen $) /($ total dosen tetap $)\} \times 100 \%$ \\
\hline & 8. Rasio buku ajar / diktat yang ada. & $\{($ Jumlah buku ajar)/(total mata kuliah) $\} \times 100 \%$ \\
\hline & 9. Rasio SAP, GBPP dan silabus yang ber-KKNI & $\begin{array}{l}\{(\text { Jumlah mata kuliah yg memiliki SAP, GBPP dan silabus yang ber- } \\
\mathrm{KKNII} /(\text { total mata kuliah })\} \times 100 \%\end{array}$ \\
\hline & 10. Rasio penilaian quisioner PBM & $\{($ Nilai rata-rata quisioner//(5)\} $\times 100 \%$ \\
\hline \multirow{3}{*}{$\begin{array}{c}\text { Peningkatan } \\
\text { kualitas dan jumlah } \\
\text { peminat maupun } \\
\text { lulusan }\end{array}$} & 11. Rasio waktu studi & $\{$ (Rata-rata waktu studi)/(6 tahun $)\} \times 100 \%$ \\
\hline & 12. $\quad$ Rasio IPK lulusan & $\{($ Rata-rata IPK $) /(4)\} \times 100 \%$ \\
\hline & 13. Rasio peminat & $\{($ Jumlah peminat)/(jumlah mahasiswa yang mendaftar kembali) $\} \times 100 \%$ \\
\hline \multirow{5}{*}{$\begin{array}{l}\text { Peningkatan } \\
\text { hardskill dan soft } \\
\text { skill Mahasiswa }\end{array}$} & 14. Rasio jumlah pengunjung Ruang Baca & $\{$ (Jumlah pengunjung Ruang baca)/(jumlah mahasiswa aktif) $\} \times 100 \%$ \\
\hline & 15. Rasio Kegiatan Himpunan Mahasiswa & $\{($ Jumlah kegiatan HMM)/(12)\} $\times 100 \%$ \\
\hline & $\begin{array}{l}\text { 16. Rasio Penghargaan atas prestasi mahasiswa di } \\
\text { bidang nalar, bakat dan minat. }\end{array}$ & $\{($ Jumlah penghargaan mahasiswa)/(jumlah mahasiswa aktif) $\} \times 100 \%$ \\
\hline & 17. Rasio mahasiswa penerima bea siswa & $\{($ Jumlah perolehan bea siswa)/(jumlah mahasiswa aktif $)\} \times 100 \%$ \\
\hline & 18. Rasio mahasiswa pemenang PKM & $\{($ Jumlah perolehan PKM)/(jumlah mahasiswa aktif $)\} \times 100 \%$ \\
\hline \multirow{4}{*}{$\begin{array}{l}\text { Peningkatan } \\
\text { penelitian dan } \\
\text { pengabdian }\end{array}$} & 19. Rasio penelitian dosen yang di danai & $\{($ Jumlah penelitian yang di danai)/(jumlah dosen aktif) $\} \times 100 \%$ \\
\hline & 20. Rasio pengabdian dosen yang di danai & $\{($ Jumlah pengabdian yang di danai)/(jumlah dosen aktif) $\} \times 100 \%$ \\
\hline & 21. Rasio artikel ilmiah yang dipublikasikan. & $\{($ Jumlah artikel yang dihasilkan dosen)/(jumlah dosen aktif $)\} \times 100 \%$ \\
\hline & 22. $\quad$ Rasio seminar/proseeding Internasional. & $\begin{array}{l}\{(J u m l a h \text { proseeding internasional yg dihasilkan dosen)/(jumlah dosen aktif)\} } x \\
100 \%\end{array}$ \\
\hline \multirow{2}{*}{$\begin{array}{l}\text { Peningkatan peran } \\
\text { Alumni dan institusi } \\
\text { swasta/pemerintah }\end{array}$} & 23. Pendapat pengguna lulusan terhadap mutu alumni. & $\{($ Rata-rata nilai kepuasan $) /(5)\} \times 100 \%$ \\
\hline & $\begin{array}{l}\text { 24. Kegiatan kerjasama dengan instansi swasta / } \\
\text { pemerintah }\end{array}$ & $\{($ Jumlah MOU $) /(12)\} \times 100 \%$ \\
\hline
\end{tabular}

\section{1 Hasil Implementasi Pengukuran Kinerja}

Pengukuran kinerja dimulai dari periode semester 1, dimana patokan nilai performance indicator awal adalah 300. Nilai ini didapat dari ratarata nilai seluruh periode pengukuran untuk semua $\mathrm{KPI}$. Ada tiga score penting di dalam perangkingan 
yaitu score 0 yang menunjukkan kondisi kinerja terburuk Jurusan, score 3 yang menunjukkan kondisi kinerja rata-rata Jurusan, score 10 yang menunjukkan kondisi kinerja terbaik Jurusan (target pencapaian kinerja). Jika nantinya Jurusan telah mencapai score 10 berarti Tabel Omax harus diperbaharui dengan target yang lebih tinggi. Demikian seterusnya sehingga perbaikan kinerja secara terus menerus (continous improvement) dapat dilakukan.

Performance Indicator dari periode 1 sebesar 322,80 dan mengalami peningkatan sebesar 7,6\% dibanding Performance Indicator rata-rata 300. Pada periode 1 ini $5 \mathrm{KPI}$ berada di atas rata-rata. KPI yang memiliki performance rating 8 adalah KPI 11 tentang rasio waktu studi dan KPI 14 tentang kunjungan pada ruang baca. Performance Indicator dari periode 2 sebesar 352,50 dan mengalami peningkatan sebesar 9,2\% dibanding periode 1 dimana pencapaian tertinggi pada KPI 16 yaitu rasio prestasi mahasiswa di bidang nalar, bakat, dan minat yang memiliki performance rating 9. Performance Indicator dari periode 3 sebesar 354,66 dan mengalami peningkatan $0,61 \%$ dibanding periode 2 .

Performance Indicator dari periode 4 sebesar 354,52 dan mengalami sedikit penurunan 0,04\% dibanding periode 3. Performance Indicator dari periode 5 sebesar 573,35 dan mengalami peningkatan yang sangat tajam $61,73 \%$ dibanding periode 4 dimana hanya dua KPI yang memiliki performance rating dibawah rata-rata. Performance Indicator dari periode 6 sebesar 606,68 dan mengalami peningkatan sebesar 5,81\% dibanding periode 5 dan merupakan periode yang memiliki performance indicator tertinggi.

Kinerja masing-masing KPI per periode sebagian besar memiliki tren yang meningkat (seluruh grafik kinerja masing-masing KPI dapat dilihat pada bagian lampiran), hanya ada beberapa KPI yang memiliki lampu merah (Traffic Light System) yang artinya perlu mendapat perhatian khusus oleh Jurusan yaitu: - KPI 6 : KPI ini memiliki bobot sebesar 4,3\%. Dari grafik pada lampiran terlihat bahwa kinerja jurusan pada KPI 6 mengalami kecenderungan menurun. KPI 6 ini merupakan indikator kinerja jurusan atas pencapaian Hak atas Kekayaan Intelektual (HaKI) yang memang sangat sulit untuk mendapatkannya. Langkah yang dilakukan jurusan, fakultas maupun universitas sudah baik seperti mengirim dosendosen yang memiliki penelitian yang berpotensi memperoleh $\mathrm{HaKI}$ untuk mengikuti beberapa workshop maupun pelatihan tentang HaKI.

- KPI 10 : KPI ini memiliki bobot yang terbilang tinggi yiatu 9,28 \% terhadap bobot total kinerja per periode. Pencapain di periode 6 lebih kecil dibandingkan periode 1 bahkan pada periode $3 \mathrm{KPI}$ ini mengalami kinerja yang sangat buruk. Berfluktuasinya kinerja KPI 10 ini disebabkan makin tingginya standar kepuasan dari stakeholder terhadap kinerja Jurusan dari periode-periode berjalan.

- KPI 17 : KPI ini merupakan indikator kinerja yang mengukur rasio jumlah mahasiswa yang menerima beasiswa terhadap jumlah mahasiswa aktif. KPI ini memiliki bobot yang kecil yaitu sebesar 2,4\% terhadap bobot total kinerja. Kinerja KPI 17 ini sangat berfluktuatif dan sangat dipengaruhi faktor eksternal yaitu jumlah instansi, badan, atau perusahaan pemberi beasiswa tersebut. Sehingga ini merupakan tantangan bagi jurusan untuk lebih aktif mencari tambahan sumber pemberi bea siswa tersebut.

Tabel 3. Hasil Rancangan Tabel Omax Periode Semester Ganjil 2014/2015

\begin{tabular}{|c|c|c|c|c|c|c|c|c|c|c|c|c|c|c|c|c|c|c|c|c|c|c|c|c|}
\hline \multicolumn{25}{|c|}{$\begin{array}{c}\text { PENGUKURAN KINERJA MODEL OBJECTIVES MATRIX } \\
\text { JURUSAN TEKNIK MESIN FAKULTAS TEKNIK UNIVERSITAS UDAYANA } \\
\text { PERIODE } 1 \\
\end{array}$} \\
\hline KPI 1 & KPI 2 & KPI 3 & KPI 4 & KPI 5 & KPI 6 & KP17 & KPI 8 & KPI 9 & KPI 10 & KPI 11 & KPI 12 & KPI 13 & KPI 14 & KPI 15 & KPI 16 & KPI 17 & KPI 18 & KPI 19 & KPI 20 & KPI 21 & KPI 22 & KPI 23 & KPI 24 & KPI \\
\hline 0,432 & 0,932 & 0,778 & 0,886 & 0,961 & 0,045 & 0,853 & 0,703 & $\mid$\begin{tabular}{||l} 
\\
0,781
\end{tabular} & 0,860 & 0,917 & 0,816 & 6,120 & || 3,027 & 0,333 & 0,009 & 0,199 & 0,006 & 0,537 & 0,415 & 1,317 & | 0,585 & 0,762 & 0,750 & PERFORMANCE \\
\hline 00,469 & \begin{tabular}{|l|l|}
0,995 \\
\end{tabular} & 0,967 & 0,9966 & \begin{tabular}{|l|}
0,978 \\
\end{tabular} & 0,063 & 0,941 & 0,908 & $\mid 0,970$ & \begin{tabular}{|l|l|}
0,940 \\
\end{tabular} & \begin{tabular}{|l|l|}
0,849 \\
\end{tabular} & $0,0,856$ & \begin{tabular}{||l|l}
9,805 \\
\end{tabular} & $\mid 3,757$ & \begin{tabular}{|l|}
0,528 \\
\end{tabular} & \begin{tabular}{|l|l}
0,015 \\
\end{tabular} & \begin{tabular}{|l|l|}
0,239 \\
\end{tabular} & \begin{tabular}{|l|}
0,017 \\
\end{tabular} & \begin{tabular}{|l|}
0,987 \\
\end{tabular} & \begin{tabular}{||l|l|}
0,952 \\
\end{tabular} & \begin{tabular}{|l|l|}
1,863 \\
\end{tabular} & \begin{tabular}{|l|l|}
0,702 \\
\end{tabular} & \begin{tabular}{|l|l|}
0,837 \\
\end{tabular} & \begin{tabular}{|l|l|}
1,199 \\
\end{tabular} & 10 \\
\hline $\begin{array}{ll}0,467 \\
\end{array}$ & 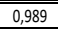 & 0,950 & 0 & \begin{tabular}{|l|l|}
0,976 \\
\end{tabular} & $\begin{array}{ll}0,058 \\
0\end{array}$ & $\begin{array}{ll}0,929 \\
\end{array}$ & $\begin{array}{l}0,8899 \\
0,\end{array}$ & 0,950 & \begin{tabular}{|l|l|}
0,919 \\
\end{tabular} & \begin{tabular}{|l|l|}
0,855 \\
\end{tabular} & $\begin{array}{ll}0,852 \\
\end{array}$ & 9,455 & 3,583 & \begin{tabular}{|l|l|}
0,510 \\
\end{tabular} & \begin{tabular}{|l|l|}
0,014 \\
\end{tabular} & 0,236 & \begin{tabular}{|l|l|}
0,016 \\
\end{tabular} & \begin{tabular}{|l}
0,946 \\
\end{tabular} & \begin{tabular}{|l|l|} 
\\
\end{tabular} & \begin{tabular}{|l|l|l|}
1,812 \\
\end{tabular} & 0,684 & \begin{tabular}{|l|l}
0,828 \\
\end{tabular} & 1,155 & 9 \\
\hline 0,464 & \begin{tabular}{|l|l|}
0,984 \\
\end{tabular} & 0,934 & $0,0,979$ & \begin{tabular}{|l|l|}
0,973 \\
\end{tabular} & 0,052 & \begin{tabular}{|l|l}
0,917 \\
\end{tabular} & 0,870 & 0,931 & \begin{tabular}{|l|l|}
0,898 \\
\end{tabular} & \begin{tabular}{|l|l|}
0,862 \\
\end{tabular} & 0,8449 & \begin{tabular}{|l|l|}
9,105 \\
\end{tabular} & \begin{tabular}{|l|}
3,409 \\
\end{tabular} & \begin{tabular}{|l|l|}
0,492 \\
\end{tabular} & \begin{tabular}{|l|}
0,013 \\
\end{tabular} & \begin{tabular}{|l}
0,232 \\
\end{tabular} & \begin{tabular}{|l|}
0,015 \\
\end{tabular} & \begin{tabular}{|l|l|}
0,905 \\
\end{tabular} & \begin{tabular}{|l}
0,850 \\
\end{tabular} & \begin{tabular}{|l|}
1,761 \\
\end{tabular} & \begin{tabular}{|l|l|}
0,666 \\
\end{tabular} & \begin{tabular}{|l|l|}
0,819 \\
\end{tabular} & \begin{tabular}{|l|l|l|}
1,111 \\
\end{tabular} & 8 \\
\hline 0,461 & \begin{tabular}{|l|l|}
0,978 \\
\end{tabular} & \begin{tabular}{|l}
0,917 \\
\end{tabular} & 0,970 & \begin{tabular}{|l|l}
0,971 \\
\end{tabular} & 0,046 & 0,905 & 0,851 & 0,912 & \begin{tabular}{|l|}
0,877 \\
\end{tabular} & \begin{tabular}{|l|l}
0,868 \\
\end{tabular} & \begin{tabular}{|l}
0,845 \\
\end{tabular} & 8,755 & 3,236 & 0,474 & \begin{tabular}{|l|l}
0,013 \\
\end{tabular} & \begin{tabular}{|l}
0,228 \\
\end{tabular} & \begin{tabular}{|l|}
0,014 \\
\end{tabular} & \begin{tabular}{|l|}
0,864 \\
\end{tabular} & 0,799 & \begin{tabular}{|l|l|}
1,710 \\
\end{tabular} & \begin{tabular}{|l}
0,648 \\
\end{tabular} & \begin{tabular}{|l|}
0,810 \\
\end{tabular} & \begin{tabular}{|l|}
1,066 \\
\end{tabular} & 7 \\
\hline 0,459 & \begin{tabular}{|l}
0,972 \\
\end{tabular} & \begin{tabular}{|l}
0,901 \\
\end{tabular} & \begin{tabular}{|l}
0,961 \\
\end{tabular} & \begin{tabular}{|l|}
0,968 \\
\end{tabular} & 0,040 & \begin{tabular}{|l}
0,893 \\
\end{tabular} & 0,832 & 0,893 & \begin{tabular}{|l|l|}
0,856 \\
\end{tabular} & \begin{tabular}{|l|l}
0,875 \\
\end{tabular} & \begin{tabular}{|l|l}
0,842 \\
\end{tabular} & \begin{tabular}{|l|}
8,405 \\
\end{tabular} & \begin{tabular}{|ll}
3,062 \\
\end{tabular} & \begin{tabular}{|l|}
0,457 \\
\end{tabular} & \begin{tabular}{|l|l}
0,012 \\
\end{tabular} & 0,225 & \begin{tabular}{|l|l}
0,013 \\
\end{tabular} & \begin{tabular}{|l|l|l}
0,823 \\
\end{tabular} & \begin{tabular}{|l|l}
0,748 \\
\end{tabular} & \begin{tabular}{|l|}
1,659 \\
\end{tabular} & \begin{tabular}{|l|}
0,630 \\
\end{tabular} & \begin{tabular}{|l|}
0,801 \\
\end{tabular} & \begin{tabular}{|l|}
1,022 \\
\end{tabular} & 6 \\
\hline 0,456 & \begin{tabular}{|l|l|}
0,966 \\
\end{tabular} & 0,885 & 0,953 & \begin{tabular}{|l|l|}
0,966 \\
\end{tabular} & 0,034 & 0,881 & 0,813 & 0,874 & \begin{tabular}{|l|l|}
0,835 \\
\end{tabular} & \begin{tabular}{|l|l|}
0,881 \\
\end{tabular} & 0 & \begin{tabular}{|l|l|}
8,056 \\
\end{tabular} & 2,888 & \begin{tabular}{|l|l|}
0,439 \\
\end{tabular} & \begin{tabular}{|l|l|}
0,011 \\
\end{tabular} & \begin{tabular}{|l|l|}
0,221 \\
\end{tabular} & \begin{tabular}{|l|l|}
0,012 \\
\end{tabular} & \begin{tabular}{|l|l}
0,782 \\
\end{tabular} & \begin{tabular}{|l|l|}
0,697 \\
\end{tabular} & \begin{tabular}{|l|l|}
1,608 \\
\end{tabular} & \begin{tabular}{|l|l}
0,612 \\
\end{tabular} & \begin{tabular}{|l|l|}
0,793 \\
\end{tabular} & \begin{tabular}{|l|l|}
0,978 \\
\end{tabular} & 5 \\
\hline 0,453 & \begin{tabular}{|l|l|}
0,960 \\
\end{tabular} & \begin{tabular}{|l|l}
0,868 \\
\end{tabular} & \begin{tabular}{|l|l}
0,944 \\
\end{tabular} & \begin{tabular}{|l|l|l}
0,963 \\
\end{tabular} & 0,029 & \begin{tabular}{|l|l|l}
0,870 \\
\end{tabular} & 0,794 & 0,855 & \begin{tabular}{|l|}
0,814 \\
\end{tabular} & \begin{tabular}{|l|l|}
0,888 \\
\end{tabular} & \begin{tabular}{|l}
0,835 \\
\end{tabular} & \begin{tabular}{|l|l|}
7,706 \\
\end{tabular} & 2,714 & \begin{tabular}{|l}
0,421 \\
\end{tabular} & \begin{tabular}{|l|}
0,010 \\
\end{tabular} & \begin{tabular}{|l|}
0,217 \\
\end{tabular} & \begin{tabular}{|l|}
0,011 \\
\end{tabular} & \begin{tabular}{|l|}
0,741 \\
\end{tabular} & 0,646 & \begin{tabular}{|l}
1,557 \\
\end{tabular} & \begin{tabular}{|l|}
0,594 \\
\end{tabular} & \begin{tabular}{|l}
0,784 \\
\end{tabular} & \begin{tabular}{|l|}
0,933 \\
\end{tabular} & 4 \\
\hline 0,451 & \begin{tabular}{|l|l}
0,955 \\
\end{tabular} & \begin{tabular}{|l}
0,852 \\
\end{tabular} & \begin{tabular}{|l}
0,936 \\
\end{tabular} & \begin{tabular}{|l|l|}
0,960 \\
\end{tabular} & 0,023 & \begin{tabular}{|l|l|l}
0,858 \\
\end{tabular} & 0,775 & 0,836 & \begin{tabular}{|l|}
0,793 \\
\end{tabular} & \begin{tabular}{|l|l}
0,8944 \\
\end{tabular} & \begin{tabular}{|l|l}
0,832 \\
\end{tabular} & 7,356 & $2,5,500$ & \begin{tabular}{|l|l|}
0,403 \\
\end{tabular} & \begin{tabular}{|l|l|}
0,009 \\
\end{tabular} & \begin{tabular}{|l|}
0,214 \\
\end{tabular} & \begin{tabular}{|l|}
0,010 \\
\end{tabular} & \begin{tabular}{|l|}
0,700 \\
\end{tabular} & \begin{tabular}{|l|}
0,595 \\
\end{tabular} & \begin{tabular}{|l|}
1,506 \\
\end{tabular} & \begin{tabular}{|l|l|}
0,576 \\
\end{tabular} & \begin{tabular}{|l|}
0,775 \\
\end{tabular} & \begin{tabular}{|l|}
0,889 \\
\end{tabular} & 3 \\
\hline 0,445 & \begin{tabular}{|l|l|}
0,941 \\
\end{tabular} & \begin{tabular}{|l|l|l}
0,814 \\
\end{tabular} & $0,0,915$ & \begin{tabular}{|l|l}
0,954 \\
\end{tabular} & 0,009 & $\begin{array}{l}0,830 \\
\end{array}$ & 0,730 & 0,792 & \begin{tabular}{|l|l|}
0,744 \\
\end{tabular} & \begin{tabular}{|l|l|}
0,910 \\
\end{tabular} & \begin{tabular}{|l|l}
0,824 \\
\end{tabular} & 6,540 & 2,134 & \begin{tabular}{|l}
0,361 \\
\end{tabular} & \begin{tabular}{|l|l}
0,007 \\
\end{tabular} & 0,205 & \begin{tabular}{|l|}
0,007 \\
\end{tabular} & \begin{tabular}{|l|l}
0,605 \\
\end{tabular} & 0,476 & 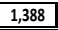 & 0,534 & \begin{tabular}{|l|}
0,754 \\
\end{tabular} & 0,785 & 2 \\
\hline 0,438 & \begin{tabular}{|l|}
0,927 \\
\end{tabular} & \begin{tabular}{|l}
0,775 \\
\end{tabular} & 0,895 & \begin{tabular}{|l|l}
0,948 \\
\end{tabular} & $-0,004$ & \begin{tabular}{|l}
0,803 \\
\end{tabular} & 0,686 & \begin{tabular}{|l|l}
0,747 \\
\end{tabular} & \begin{tabular}{|l|l|}
0,695 \\
\end{tabular} & \begin{tabular}{|l|l}
0,925 \\
\end{tabular} & 0,816 & 5,724 & $\mid$\begin{tabular}{|l}
1,729 \\
\end{tabular} & \begin{tabular}{|l|}
0,319 \\
\end{tabular} & \begin{tabular}{|l|l|}
0,005 \\
\end{tabular} & \begin{tabular}{|l|}
0,197 \\
\end{tabular} & \begin{tabular}{|l}
0,005 \\
\end{tabular} & \begin{tabular}{|l|}
0,509 \\
\end{tabular} & \begin{tabular}{|l|l}
0,357 \\
\end{tabular} & \begin{tabular}{|l|}
1,269 \\
\end{tabular} & \begin{tabular}{|l|l}
0,492 \\
\end{tabular} & \begin{tabular}{|l}
0,734 \\
\end{tabular} & \begin{tabular}{|l|l}
0,682 \\
\end{tabular} & 1 \\
\hline 0,432 & \begin{tabular}{|l|l|}
0,914 \\
\end{tabular} & \begin{tabular}{|l}
0,737 \\
\end{tabular} & 0,875 & \begin{tabular}{|l|l|}
0,942 \\
\end{tabular} & $-0,018$ & 0,775 & 0,641 & 0,703 & \begin{tabular}{|l|l|}
0,647 \\
\end{tabular} & \begin{tabular}{|l||}
0,940 \\
\end{tabular} & 0,808 & \begin{tabular}{||l|l|}
4,907 \\
\end{tabular} & 1,323 & \begin{tabular}{|l|l|}
0,277 \\
\end{tabular} & \begin{tabular}{|l|l}
0,003 \\
\end{tabular} & \begin{tabular}{|l|l|}
0,188 \\
\end{tabular} & \begin{tabular}{|l|l|}
0,003 \\
\end{tabular} & \begin{tabular}{|l|l|}
0,413 \\
\end{tabular} & \begin{tabular}{|l|l|}
0,238 \\
\end{tabular} & \begin{tabular}{|l|}
1,150 \\
\end{tabular} & \begin{tabular}{|l|l|}
0,450 \\
\end{tabular} & \begin{tabular}{|l|l|}
0,713 \\
\end{tabular} & \begin{tabular}{|l|l|}
0,579 \\
\end{tabular} & 0 \\
\hline$\overline{0}$ & $\overline{2}$ & $\overline{2}$ & $\overline{\overline{0}}$ & $\overline{74}$ & $\overline{\overline{6}}$ & $\overline{\overline{3}}$ & $\overline{2}$ & $\overline{2}$ & 7 & $\overline{88}$ & $\overline{22}$ & 2 & $\overline{88}$ & 2 & 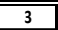 & $\overline{2}$ & $\overline{2}$ & 2 & 2 & $\overline{2}$ & 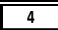 & 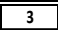 & 2 & 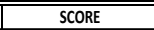 \\
\hline 6,00 & 2,77 & 2,02 & 6,35 & \begin{tabular}{|l|}
3,47 \\
\end{tabular} & 4,30 & 6,00 & $\begin{array}{l}4,29 \\
\end{array}$ & 2,69 & \begin{tabular}{|c|}
9,28 \\
\end{tabular} & 7,38 & \begin{tabular}{|l|}
5,41 \\
\end{tabular} & 2,66 & 1,21 & \begin{tabular}{|l|}
1,61 \\
\end{tabular} & 3,17 & 2,40 & \begin{tabular}{|l|}
2,72 \\
\end{tabular} & \begin{tabular}{|l|}
4,32 \\
\end{tabular} & 4,32 & \begin{tabular}{|l|}
3,69 \\
\end{tabular} & \begin{tabular}{|l|l}
5,20 \\
\end{tabular} & \begin{tabular}{|l|}
5,81 \\
\end{tabular} & \begin{tabular}{|l|}
2,91 \\
\end{tabular} & WEIGHT \\
\hline 0,000 & 5,537 & \begin{tabular}{|l}
4,047 \\
\end{tabular} & 0,000 & $\begin{array}{ll}13,860 \\
\end{array}$ & 25,821 & 18,007 & 8,587 & 5,388 & \begin{tabular}{|l|}
64,985 \\
\end{tabular} & 59,045 & 10,813 & 5,321 & 9,703 & \begin{tabular}{|l|}
3,216 \\
\end{tabular} & \begin{tabular}{|l|}
9,500 \\
\end{tabular} & 4,809 & \begin{tabular}{|l|}
5,444 \\
\end{tabular} & \begin{tabular}{|l|l|}
8,640 \\
\end{tabular} & 8,640 & \begin{tabular}{|l|l|}
7,388 \\
\end{tabular} & \begin{tabular}{|l|}
20,787 \\
\end{tabular} & 17,443 & 5,814 & VALUE \\
\hline & & & & & & & & 322,80 & & & & & 300,00 & & & & & & & & & & & $\begin{array}{c}\text { PERFORMANCE } \\
\text { INDICATOR } \\
\end{array}$ \\
\hline
\end{tabular}


3.2 Hasil Rancangan Tabel OMAX menyeluruh. Tabel 3 merupakan hasil rancangan Tabel OMAX yang dapat di gunakan sebagai alat ukur kinerja Jurusan Teknik Mesin Universitas Udayana. Jika nantinya pada periode tertentu KPI telah mencapai Performance 10 berarti penentuan rasio dan skor harus di hitung kembali.

\section{Simpulan}

Dari hasil penelitian disimpulkan bahwa Rancangan Sistem Pengukuran Kinerja dengan mengintegrasikan Metode Objectives Matrix (OMAX) telah berhasil dibuat dimana menentukan Key Performance Indicator (KPI) dibuat berdasarkan pendekatan Integrated Performance Measurement Systems (IPMS) serta pembobotan KPI menggunakan metode Analytical Hierarcy Process (AHP). Dari tabel Omax didapat Performance Indicator dari periode 1 sebesar 322,8 dan mengalami peningkatan $7,6 \%$ dibanding Performance Indicator rata-rata 300. Performance Indicator dari periode 2 sebesar 352,50 dan mengalami peningkatan 9,2\% dibanding periode 1 . Performance Indicator dari periode 3 sebesar 354,66 dan mengalami sedikit peningkatan $0,61 \%$ dibanding periode 2. Performance Indicator dari periode 4 sebesar 354,52 dan mengalami sedikit penurunan $0,04 \%$ dibanding periode 3 . Performance Indicator dari periode 5 sebesar 573,35 dan mengalami peningkatan $61,73 \%$ dibanding periode 4. Performance Indicator dari periode 6 sebesar 606,68 dan mengalami peningkatan $5,81 \%$ dibanding periode 5 dan merupakan periode dengan Performance Indicator tertinggi dalam sistem pengukuran ini.

\section{Ucapan Terima Kasih}

Penulis menyampaikan ucapan terima kasih kepada Direktorat Jenderal Pendidikan Tinggi Kemenristekdikti, LPPM Universitas Udayana, dan Pimpinan Fakultas Teknik Universitas Udayana yang telah membiayai penelitian ini.

\section{Daftar Pustaka}

[1] Dimyati, T.T dan Dimyati, Ahmad (1994) "Operation Research": Model-Model Pengambilan Keputusan', Cetakan Ketiga, PT Sinar Baru Algensindo, Bandung

[2] Gazpersz, Vincent (1998) "Manajeme Produktivitas Total": Edisi 1, PT Gramedia Pustaka Utama, Jakarta

[3] Penindra, I.M.D.Budiana (2013) "Peningkatan Produktivitas Pada Fakultas Teknik Jurusan Teknik Mesin Universitas Udayana Melalui Perancangan Sistem Pengukuran Kinerja Yang Terintregasi", Prosiding Seminar Nasional Mesin dan Industri 2003, Univ Tarumanagara, Jakarta
[4] Putra, J.R (1988) "Dasar-dasar Produktivitas": Edisi 1, Karunia, Universitas Indonesia, Jakarta

[5] Riggs, J.L (1987) "Productio System: Planning, Analysis, and Control". Edisi 4, John Wiley and Sons, New York.

[6] Saaty, T.L (1993) "Pengambilan Keputusan Bagi Para Pemimpin: Proses Hirarki Analitik untuk Pengambil Keputusan Dalam Situasi yang Kompleks" PT Pustaka Binaman Pressindo, Jakarta.

[7] Sinungan, Muchdarsyah (2000) "Produktivitas Apa dan Bagaimana", Edisi 2 PT Bumi Aksara, Jakarta

[8] Summanth, D.J (1984) "Productivity Engineering and Management”, Edisi 3, McGraw Hill Company, New York.

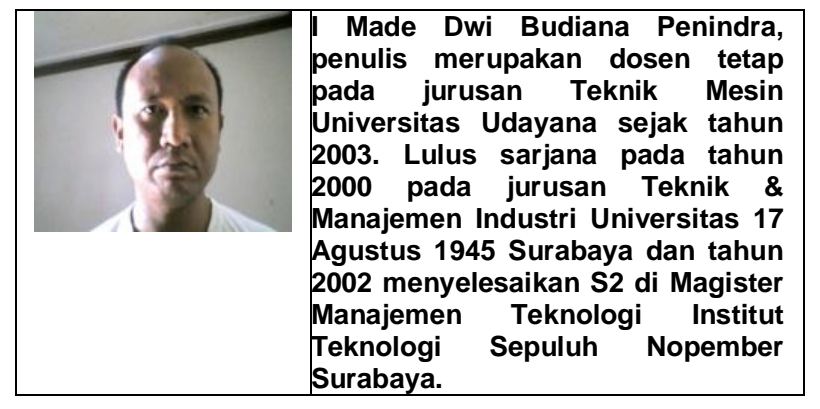

